\title{
Improving the Compliance of Fluid Diet of Patients with Chronic Kidney Failure with Family Support-Based Health Education
}

\author{
Tata Mahyuvi ${ }^{1}$, Siti Nur Hasina ${ }^{2}$ \\ ${ }^{1}$ Islamic Hospital of Surabaya \\ Indonesia \\ ${ }^{2}$ Faculty of Nursing and Midwifery, \\ Universitas Nahdlatul Ulama \\ Surabaya, Indonesia \\ Email: \\ mahyuvi1922@gmail.com
}

Received : October $4^{\text {nd }} 2021$

Accepted : October $15^{\text {rd }} 2021$

Published : November $27^{\text {th }} 2021$

\begin{abstract}
Background: Failure of kidney function can lead to complications of other health problems, one of which is the condition of excess fluid volume caused by non-compliance with fluid dietary restrictions so that it triggers hypervolemia and results in excessive circulation burden, edema, cardiovascular disorders, impaired cognitive function and can lead to cause death. It is expected that patients with chronic renal failure undergoing hemodialysis therapy can comply with the prescribed fluid diet restrictions. Therefore, in increasing compliance, strong support is needed regarding the importance of fluid diet restriction management.

Objective: The purpose of this study was to analyze the Effect of Family Support-Based Health Education on Fluid Diet Compliance in Chronic Kidney Failure Patients.

Methods: The design of this study was a quasi-experimental with a pre and post design approach. The population of all patients with chronic kidney failure at Islamic Hospital Of Surabaya A. Yani was 82 patients. The sample size is 48 respondents. The sampling technique used simple random sampling. Patients are given family support-based health education in an effort to increase health knowledge in improving the health status of patients with chronic kidney failure with a family support approach to improve adherence to the fluid intake diet. The analysis used the Wilcoxon Signed Ranks test with $\mathrm{p}$ value $<0.05$.

Results: The results of this study indicate $p=0.000$ which means that there is a significant effect of Fluid Diet Adherence before and after Family Support-Based Health Education.

Conclusion: Family Support-Based Health Education is effective in improving Fluid Diet Adherence in patients with chronic renal failure and is highly recommended for patients undergoing hemodialysis therapy.
\end{abstract}

Keywords: Family support-based health education, compliance, chronic kidney failure

Copyright (C) 2021 IIK STRADA Indonesia All right reserved.

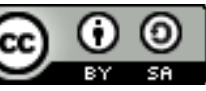

This is an open-acces article distributed under the terms of the Creative Commons AttributionShareAlike 4.0 International License. 


\section{INTRODUCTION}

Failure of kidney function can lead to complications of other health problems, one of which is the condition of excess fluid volume due to non-compliance with fluid dietary restrictions so that it triggers hypervolemia and results in excessive circulation burden, edema, cardiovascular disorders, impaired cognitive function and can cause death (Wijaya et al., 2018). Chronic renal failure patients undergoing hemodialysis therapy are mostly difficult to control fluid diet restrictions, causing therapy failure which can reduce the patient's quality of life. It is expected that patients with chronic renal failure undergoing hemodialysis therapy can comply with the prescribed fluid diet restrictions. Therefore, in increasing compliance, strong support is needed regarding the importance of fluid diet restriction management.

The incidence of chronic kidney failure in the world is 661.648 people and is a global health threat. The non-adherence rate of chronic kidney failure patients undergoing hemodialysis therapy in limiting fluid diets reaches 79.5 percent and in China the number of chronic kidney failure patients who do not comply with hemodialysis to fluid diet restrictions ranges from 43.6 to 54.9 percent (Nursalam. et al., 2020). Data from the Indonesian Renal Registry in 2017 stated that the number of patients with chronic kidney failure in Indonesia was 77.892 new patients and 30,831 active patients. The most dominant causes of chronic kidney failure are hypertension and diabetes mellitus (IRR, 2018).

Riskesdas data (2018) said that in the last 5 years the incidence of chronic kidney failure in East Java was quite high, reaching 113.045 patients. Data at the Islamic Hospital Surabaya A. Yani the number of visits with chronic kidney failure patients undergoing hemodialysis therapy in JanuaryMarch 2021 was 2248 visits. The results of interviews with researchers from 10 patients with chronic kidney failure at the Surabaya Islamic Hospital A. Yani, 8 of whom still do not comply with fluid diet restrictions.

Behavior in fluid diet compliance in patients with chronic kidney failure is a specific thing and differs from one individual to another. Non-compliance can lead to exacerbation of health problems that are being suffered by the patient. Most patients with chronic renal failure experience excess fluid volume as a result of non-compliance in restricting fluid diet (Kurniawati et al., 2015). Factors that can affect the compliance of chronic kidney failure patients in fluid diet include age, education, duration of hemodialysis therapy, knowledge, motivation, access and patient perception of nursing services, health education and family support. Patient compliance can be defined as the extent to which the patient's behavior conforms to what has been determined by health professionals (Rostanti et al., 2016).

Patients who have difficulty in dieting fluid intake, because they do not pay attention to the importance of limiting the intake of fluids that enter the body. For patients with chronic renal failure, the fluid intake that enters the body must be regulated so that the weight gain obtained is no more than $2 \mathrm{~kg}$ between dialysis times (Nur et al., 2020). The recommended daily fluid intake for patients with chronic kidney failure is limited to Insensible Water Loss (IWL) plus the amount of urine that comes out (Mahyuvi, 2020). Therefore, patients who consume lots of fluids will gain weight until the next hemodialysis schedule. Restriction of fluid intake aims to reduce excess fluid volume in the interdialytic period. Excess fluid can cause edema, hypertension, and is also associated with the patient's quality of life. Hemodialysis therapy is carried out to wash and remove fluids from patients with chronic kidney failure until they reach the target dry body weight of the patient (Purnomo et al., 2018).

There are many ways that we can do to improve compliance in patients with chronic kidney failure, including health education, providing social support, family support, providing modules, conducting psych education, comprehensive education, providing counseling, and providing information support (Relawati et al., 2018). The provision of health education with a family approach (family support) is an important thing to consider in the management of patients with chronic kidney failure. The quality of interpersonal relationships between health workers, nurses and patients is significantly related to medication adherence, so that in order to achieve therapeutic success it is necessary to support health education by nurses and health workers using a family support approach.

\section{OBJECTIVE}

The purpose of this study was to analyze the effect of family support-based health education on adherence to fluid diet in patients with chronic kidney failure. 


\section{METHODS}

The design of this research is quasi experimental using pretest and posttest approach. The population of all patients with chronic kidney failure at the Islamic Hospital of Surabaya A. Yani was 82 patients in April - May 2021. A large sample of 48 respondents was obtained using simple random sampling technique. Patients are given health education based on family support, which is an effort to increase health knowledge in improving the health status of patients with chronic kidney failure with a family support approach to improve adherence to the fluid intake diet for 1 month. Analysis using the Wilcoxon Signed Ranks Test.

\section{RESULTS}

The research results obtained by the researchers are as follows:

Table 1. Frequency Distribution of Respondents' Characteristics Based on Gender, Age, Education, Occupation $(\mathrm{n}=48)$

\begin{tabular}{lcc}
\hline Characteristics of Respondents & Frequency & Percentage (\%) \\
\hline Gender & 33 & 68.8 \\
Man & 15 & 31.2 \\
Woman & 6 & \\
\hline Age & 32 & 12.5 \\
Early Adults (18-40 Years Old) & 10 & 66.7 \\
Middle Adult (41-60 Years Old) & & 20.8 \\
Elderly (> 60 years old) & 9 & 18.8 \\
\hline Education & 25 & 52.1 \\
Primary school & 14 & 29.2 \\
Junior high school & & \\
Senior High School & 17 & 35.4 \\
Occupation & 31 & 64.6 \\
Work & Does not work & \\
\hline
\end{tabular}

Based on table 1. it can be seen that some of the respondents are male, as many as 33 respondents (68.8\%) out of a total of 48 respondents. most of the respondents were aged between 41 60 years as many as 32 respondents $(66.7 \%)$ of the total 48 respondents. most of the respondents have junior high school education, namely as many as 25 respondents $(52.1 \%)$ out of a total of 48 respondents. most of the respondents do not work as many as 31 respondents $(64.6 \%)$ of the total 48 respondents

Table 2. Results of Statistical Tests on the Effect of Family Support-Based Health Education on Fluid Diet Compliance in Chronic Kidney Failure Patients

\begin{tabular}{lcccc}
\hline \multirow{2}{*}{ Compliance } & \multicolumn{2}{c}{ Before } & \multicolumn{2}{c}{ After } \\
\cline { 2 - 5 } & Frequency & Percentage $(\%)$ & Frequency & Percentage $(\%)$ \\
\hline Not obey & 19 & 39.6 & 3 & 6.3 \\
Less obedient & 24 & 50.0 & 11 & 22.9 \\
Obey & 5 & 10.4 & 34 & 70.8 \\
\hline Statistical test results Wilcoxon signed ranks test with p value $=0.000$ &
\end{tabular}

Based on table 2. above shows that before being given Family Support-Based Health Education, patients with chronic kidney failure who were less compliant were 24 respondents $(50.0 \%)$ and after being given Family Support-Based Health Education, most of the respondents, namely 34 respondents $(70.8 \%)$ complied with dietary restrictions. fluid. Based on the results of statistical tests using the Wilcoxon Signed Ranks Test value $=0.000$ then $\mathrm{H} 1$ is accepted, meaning that the Effect of Family Support-Based Health Education on Fluid Diet Compliance in Chronic Kidney Failure Patients. 


\section{DISCUSSION}

\section{Fluid diet compliance}

The results of the study based on table 2 showed that most of the patients with chronic kidney failure were obedient to fluid restriction after Family Support-Based Health Education was carried out. According to the researcher, the knowledge gained and owned by the respondents in the past coupled with the information provided by nurses can increase knowledge for the better. Another factor that can increase the respondent's knowledge is the media used and the approach of support given to the family to support the patient. This research, in addition to providing Family Support-Based Health Education, further reinforcement is carried out so that it strengthens respondents to increase the level of compliance. The Family Support-Based Health Education material presented was also an interesting thing for the respondents because it relates to the efforts that must be made by patients with chronic kidney failure undergoing hemodialysis therapy so that they can feel comfortable before, during and after hemodialysis therapy in the hospital.

Family Support-Based Health Education is a process that includes assessment, intervention and evaluation with a family support approach, where the role of the family is needed in controlling the patient's dietary behavior (Mohamed, 2014). Assessment can be useful as a determinant of needs, motivations and learning objectives that are made jointly and agreed upon by the client with the family. Interventions are carried out to provide learning resources as needed by the client with a family support approach and evaluations are carried out during the learning process and at each stage of learning to determine the abilities that have been achieved. Re-learning and follow-up of abilities can be done if needed (Ryu et al., 2014).

The purpose of Family Support-Based Health Education is to change behavior

individuals or communities in the health sector, especially in patients with chronic kidney failure to comply with fluid intake with a family support approach. Educational media is a tool used to assist in conveying educational or teaching materials and information to patients.

The level of success can be achieved by someone through 3 stages of compliance, including: first is to believe in the accuracy of the diagnosis, the suitability of the therapy given, the ability to carry out therapy as well as validation and the tendency of therapy to achieve success. When patients with chronic kidney failure undergoing hemodialysis therapy have a basis of belief, then patients with chronic kidney failure will adapt to their illness conditions and the therapy that must be undertaken due to suffering from the disease. The second stage is knowledge. A person needs to know what to do in order to carry out these actions correctly and correctly. Clear instructions and well-developed mental models can help individuals to take action effectively. Good knowledge of when and how to carry out a therapy will be able to help patients with chronic kidney failure to develop critical instructions and remind them to always obey and adhere to the recommendations for the therapy given. The last stage is action. Patients with chronic kidney failure will obey the recommendations for the given therapy if they believe in the goals and effectiveness of the therapy and know how to carry out the recommended therapy because every time it is implemented/not implemented is a reaffirmation of belief, knowledge and ability to act. (Cobra Parvan et al., 2015).

The results of the study are based on table 2. using a statistical test using the Wilcoxon Signed Ranks Test value $=0.000$ so that there is a significant effect between Family Support-Based Health Education on Fluid Diet Compliance in Chronic Kidney Failure Patients. There is no standard intervention on how to improve compliance, because there are many different aspects that play a role in influencing a person's compliance. The use of educational methods using a family support approach in providing health education increases the value of knowledge and adherence to therapy and diet ( $\mathrm{K}$ Parvan et al., 2016).

According to the researcher, the Family Support-Based Health Education intervention on the respondent's level of compliance occurs because the information provided is information that is generally known to be true by patients with strengthened monitoring by the family every day. Patients with chronic kidney failure know that fluid restriction is needed so as not to experience serious complications that can cause discomfort and if continued can cause death. The truth of this information creates a desire to change the values that have been held so far and receive health education provided by nurses together with their families.

The results of the study above are in accordance with research (Kurniawati et al., 2015) that education increases compliance with fluid intake in patients with chronic renal failure on hemodialysis. 
This is supported by research (Wijaya et al., 2018) which states that spiritual-based health education using video has an effect on limiting fluid intake in patients with chronic kidney failure. It is also supported by research which states that (Ulfah et al., 2018) which states that education / counseling can significantly increase knowledge and compliance with fluid intake restrictions in chronic kidney failure patients undergoing hemodialysis. It is also supported that family support has a significant relationship with fluid restriction compliance in CKD patients undergoing hemodialysis (Saraswati et al., 2019).

\section{CONCLUSION}

Family Support-Based Health Education Improves Fluid Diet Compliance in Chronic Kidney Failure Patients. So the importance of the role of the family in providing motivation and attention to patients with chronic kidney failure so that in the future diet compliance has a good impact on the quality of life of patients.

\section{ACKNOWLEDGMENTS}

The research team is very grateful to all respondents at the Surabaya Islamic Hospital A. Yani. Thanks to A. Yani Hospital for allowing this research and Nahdlatul Ulama University Surabaya for supporting and motivating this research to run well.

\section{CONFLICTS OF INTEREST}

All research teams agree with the final results of this study and there is no conflict of interest in this study.

\section{REFERENCES}

Kurniawati, D. P., Widyawati, I. Y., \& Mariyanti, H. (2015). Edukasi Dalam Meningkatkan Kepatuhan Intake Cairan Pasien Penyakit Ginjal Kronik (PGK) on Hemodialisis. Jurnal Ners, 1-7.

Mahyuvi, T. (2020). Evidence-Based Practice: Pentingnya Health Education Dalam Meningkatkan Kepatuhan Pembatasan Intake Asupan Cairan Pada Penderita Gagal Ginjal Kronik. Lembaga Mutiara Hidup Indonesia.

Mohamed, S. A. (2014). The Effectiveness of an Educational Intervention on Fatigue in Hemodialysis Patients : A Randomized Controlled Trial. IOSR Journal of Nursing and Health Science (IOSRJNHS), 3(4), 40-50.

Nur, Y. M., Johan, T., \& Hermaini, L. (2020). Pengetahuan Dan Dukungan Keluarga Terhadap Kepatuhan Diet Pasien Gagal Ginjal Kronik. Journal of Public Health, 01(01), 24-33.

Nursalam, N., Kurniawati, N. D., Putri, I. R. P., \& Priyantini, D. (2020). Automatic reminder for fluids management on confidence and compliance with fluid restrictions in hemodialysis patients. Systematic Reviews in Pharmacy, 11(5), 226-233. https://doi.org/10.31838/srp.2020.5.34

Parvan, K, Lakdizaji, S., Mohammadpoorasl, A., \& Crowley, M. (2016). The effect of an Educative Intervention about Blood Pressure Control on levels of Knowledge and Self Efficacy in Patients Undergoing Hemodialysis : A Randomized Clinical Trial The effect of an Educative Intervention about Blood Pressure Control on levels. International Journal of Medical Research \& Health Sciences, January.

Parvan, Kobra, Hasankhani, H., Seyyedrasooli, A., \& Riahi, S. M. (2015). The Effect of Two Educational Methods on Knowledge and Adherence to Treatment in Hemodialysis Patients : Clinical Trial. Journal of Caring Sciences, 4(1), 83-93. https://doi.org/10.5681/jcs.2015.009

Purnomo, M. W., Yusuf, A., \& Kartini, Y. (2018). Pengaruh Edukasi Kesehatan Berbasis Theory Of Planned Behavior Terhadap Penurunan Nilai Interdialiytic Weight Gain (IDWG) Dan Kecemasan Pasien Hemodialisa Di Rs Islam Jemursari Surabaya. Proceedings of CSW Candle.

Relawati, A., Syafriati, A., Al Hasbi, H., \& Fitria, P. N. (2018). Edukasi pasien chronic kidney disease berbasis aplikasi android: buku saku pasien. Journal of Health Studies, 2(2), 1-7. https://doi.org/10.31101/jhes.408

Rostanti, A., Bawotong, J., \& Onibala, F. (2016). Faktor Faktor Yang Berhubungan Dengan Kepatuhan Menjalani Terapi Hemodialisa Pada Penyakit Ginjal Kronik Di Ruangan Dahlia Dan Melati Rsup Prof. Dr. R. D Kandou Manado. E-Journal Keperawatan (e-Kp), 4.

Ryu, H., Jeon, H. J., Sun, H., Han, K. H., \& Whang, C. G. (2014). Repeated education improves diet compliance in maintenance Hemodialysis Patients. Nternational Journal of Urology and 
Nephrology, 2(4), 63-68.

Saraswati, N. L. G. I., Antari, N. L. Y. S., \& Suwartini, N. L. G. (2019). Hubungan Dukungan Keluarga Dengan Kepatuhan Pembatasan Cairan Pada Pasien Chronic Kidney Disease Yang Menjalani Hemodialisa. Jurnal Ilmu Kesehaan Bhakt Husada, 45-53. https://doi.org/https://doi.org/10.34305/jikbh.v10i1.84 usaha

Ulfah, M., Yuniarti, Y., \& Rahayuni, A. (2018). Efek Konseling Gizi Terhadap Pengetahuan Dan Kepatuhan Pembatasan Intake Cairan Pada Pasien Chronic Kidney Disease (CKD) Di Rsud Abdul Wahab Sjahranie Samarinda. Jurnal Nutrisia, 20(1), 27-33. https://doi.org/10.29238/jnutri.v20i1.8

Wijaya, A. K., Busjra, B., \& Azzam, R. (2018). Pengaruh Edukasi Pendekatan Spiritual Berbasis Video terhadap Kepatuhan Pembatasan Cairan Klien ESRD yang Menjalani Hemodialisa. Jurnal Keperawatan Silampari, 1(2), 17-31. https://doi.org/10.31539/jks.v1i2.97 